\title{
Aplikasi Kamus Bahasa Indonesia - Bahasa Italia Berbasis Android
}

\author{
Ike Putri Kusumawijaya \\ Program Studi Teknik Informatika Universitas Gunadarma \\ e-mail: ikeputri@staff.gunadarma.ac.id
}

\begin{abstract}
Abstrak
Perkembangan teknologi di bidang informasi maupun komunikasi mengalami peningkatan sejalan dengan perkembangan arus globalisasi. Salah satu contoh dari pertumbuhan teknologi disaat ini yakni kemajuan teknologi pada gadget dan juga ponsel pintar. Informasi dalam bentuk lisan dan juga tulisan banyak disampaikan dalam suatu bahasa yang berlainan. Sehingga benar-benar dibutuhkan media yang bisa menerjemahkan dari satu bahasa menjadi bahasa lainnya yakni kamus. Penggunaan dari media cetak konvensional diduga tidak praktis dan ekonomis bagi pengguna sehingga dibutuhkan sebuah aplikasi kamus berbasis mobile agar aplikasi tersebut dapat digunakan oleh pengguna dengan cepat dan tanpa terhalang oleh batasan ruang dan waktu. Pada aplikasi berbasis mobile terdapat beberapa platform yang bisa digunakan, contohnya adalah platform Android dengan menggunakan bahasa pemrograman Java. Tujuan dari penelitian ini adalah membuat sebuah aplikasi kamus bahasa Indonesia - bahasa Italia berbasis Android. Manfaat pengembangan aplikasi adalah untuk membantu pengguna dalam mempelajari bahasa Italia. Penelitian ini menggunakan Software Development Life Cycle sebagai metode penelitian yang digunakan. Aplikasi ini dapat menjadi tambahan referensi dalam pembelajaran bahasa Italia. Aplikasi kamus ini menyediakan dua fitur, yaitu fitur cari kata untuk mencari arti dari Indonesia ke Italia maupun sebaliknya dan fitur tambah kata untuk menambahkan kata baru sesuai keinginan pemakai.
\end{abstract}

Kata kunci: kamus, bahasa Indonesia, bahasa Italia, Android

\begin{abstract}
Technology developments in the information and communication sectors have increased in line with developments in globalization. One example of today's technology growth is technological advances in gadgets and smart phones. Information in both spoken and written form is widely conveyed in different languages. Therefore a medium that can translate from one language into another is really needed, namely a dictionary. The use of conventional print media is thought to be impractical and economical for users, so a mobile-based dictionary application is needed so that the application can be used by users quickly and without being hindered by space and time constraints. In mobile-based applications, there are several platforms that can be used, for example, the Android platform using the Java programming language. The purpose of this study is to create an Android-based dictionary application for Indonesian - Italian. The benefit of developing the application is to help users learn Italian. This study uses the Software Development Life Cycle as the research method used. This application can be an additional reference in learning Italian. This dictionary application provides two features, namely a word search feature to search for meanings from Indonesian to Italian and vice versa and a word add feature to add new words according to the user's wishes.
\end{abstract}

Keywords: dictionary, Indonesian, Italian, Android

\section{PENDAHULUAN}

Perkembangan Teknologi di bidang Informasi maupun Komunikasi mengalami peningkatan sejalan dengan perkembangan arus globalisasi. Salah satu contoh dari pertumbuhan teknologi disaat ini yakni kemajuan teknologi pada gadget dan juga ponsel pintar. Selain bisa digunakan sebagai alat komunikasi, pengguna dapat menggunakan ponsel pintar sebagai media pembelajaran. Dengan adanya media pembelajaran pada telepon seluler, para pengguna dapat belajar dan juga mendapatkan 
informasi dimana saja dan kapan saja. Sekarang manusia bisa sama-sama melakukan interaksi secara langsung serta memperoleh data yang terbaru, dimana batasan antara jarak, ruang, serta waktu tidaklah menjadi suatu penghalang untuk manusia dalam melaukan proses komunikasi dan melakukan pencarian informasi [1]. Komunikasi yang bermakna dalam suatu tatanan bahasa yang terencana dari kedua sisi dalam melakukan interaksi menjadi sebuah tolak ukur untuk menentukan apakah pesan yang disampaikan tersebut dapat diinformasikan [2].

Informasi dalam bentuk lisan dan juga tulisan banyak disampaikan dalam suatu bahasa yang berlainan. Sehingga benar-benar dibutuhkan media yang bisa menerjemahkan dari satu bahasa menjadi bahasa lainnya yakni kamus [3]. Berdasarkan Kamus Besar Bahasa Indonesia (KBBI), kamus memiliki arti yakni buku acuan yang memuat kata dan ungkapan yang biasanya disusun menurut abjad berikut keterangan tentang maknanya, pemakaianya dan terjemahannya, kamus juga dapat digunakan sebagai buku rujukan yang menerangkan makna kata-kata yang berfungsi untuk membantu seseorang mengetahui kosakata baru [4].

Pada awalnya kamus bahasa dihasilkan pada media cetak konvensional. Penggunaan dari media cetak konvensional diduga tidak praktis dan ekonomis bagi pengguna sehingga dibutuhkan sebuah aplikasi kamus berbasis mobile agar aplikasi tersebut dapat digunakan oleh pengguna dengan cepat dan tanpa terhalang oleh batasan ruang dan waktu. Pada aplikasi berbasis mobile terdapat beberapa platform yang bisa digunakan, contohnya adalah platform Android dengan menggunakan bahasa pemrograman Java. Android memakai basis kode komputer yang bisa didistribusikan secara terbuka sehingga pengguna bisa membuat aplikasi baru didalamnya dan Java bersifat multiplatform sehingga dapat digunakan pada berbagai perangkat.

Tujuan dari penelitian ini adalah membuat sebuah aplikasi kamus bahasa Indonesia - bahasa Italia berbasis Android. Aplikasi ini diharapkan dapat dijadikan tambahan referensi dalam pembelajaran bahasa Italia. Manfaat pengembangan aplikasi adalah untuk membantu pengguna dalam mempelajari bahasa Italia. Selain menyediakan fasilitas untuk pencarian kata, aplikasi ini juga memberikan kelebihan lain berupa fasilitas untuk penambahan kata, sehingga pemakai aplikasi ini dapat dengan mudah menyimpan kata baru.

\section{METODE PENELITIAN}

Penelitian ini menggunakan Software Development Life Cycle sebagai metode penelitian yang digunakan. Tahap-tahap yang dilakukan pada Software Development Life Cycle, yaitu : analisis kebutuhan, perencanaan, implementasi, dan uji coba.

A. Tahap analisis kebutuhan

Tahap pertama yang dilakukan adalah analisis kebutuhan perangkat lunak. Tahapan ini dilakukan dengan menghimpun kebutuhan pengguna secara menyeluruh yang akan dinterpretasikan sesuai dengan kebutuhan pengguna untuk memastikan hal tersebut dapat diwujudkan pada program yang akan dikembangkan khususnya untuk membuat aplikasi kamus bahasa sebagai media pembelajaran berbasis mobile. Pengumpulan data dilakukan dengan cara observasi, wawancara yang menghasilkan dokumen user requirement untuk dibuat suatu aplikasi sesuai dengan hasil kebutuhan pengguna untuk dijadikan dasar dalam tahap perancangan aplikasi. Pada tahap ini juga dilakukan penentuan database yang akan digunakan pada pembuatan aplikasi kamus bahasa Indonesia - bahasa Italia.

B. Tahap perancangan

Tahap perancangan adalah proses multi langkah yang berfokus pada desain pembuatan program perangkat lunak termasuk struktur navigasi, representasi antarmuka, dan prosedur pengodean. Pada tahap ini merupakan proses desain yang akan menerjemahkan syarat kebutuhan ke sebuah perancangan perangkat lunak yang dapat diperkirakan sebelum dibuat menggunakan bahasa pemrograman. Desain yang digunakan dalam bentuk struktur navigasi dan mockup. Struktur navigasi digunakan untuk merepresentasikan alur dari program yang akan dibuat, sedangkan mockup digunakan untuk membuat perancangan tampilan. Tahap ini menghasilkan sebuah dokumen software requirement yang akan digunakan dalam melakukan proses coding untuk pembuatan aplikasi.

C. Tahap implementasi

Pada tahap implementasi, rancangan harus dapat ditranslasikan menjadi sebuah aplikasi. 
Tahapan ini menghasilkan sebuah aplikasi sesuai dengan desain yang sudah dibuat pada tahap sebelumnya yaitu tahap perancangan. Selanjutnya adalah proses coding yang sesuai dengan analisis sistem yang telah didesain untuk membuat aplikasi ini, serta perancangan dan pembuatan basis data menggunakan MySQL. Penyusunan kode program ditulis menggunakan bahasa pemrograman Java. Tahap ini akan menghasilkan sebuah aplikasi yang diinginkan yaitu aplikasi kamus bahasa Indonesia - bahasa Italia berbasis Android

D. Tahap uji coba

Tahap terakhir yang dilakukan yakni tahap uji coba aplikasi dengan menggunakan AVD Android pada komputer dengan spesifikasi processor AMD A6-3400M 1.4GHz, RAM 4,00 GB. Pengujian berfokus pada fungsi dan logika dari aplikasi serta memastikan bahwa semua bagian dari aplikasi telah diuji. Hal ini dilakukan untuk mengurangi error dan memastikan output yang dihasilkan oleh aplikasi sudah sesuai dengan yang diinginkan. Pengujian dilakukan pada aplikasi yang sudah diimplementasikan untuk memastikan bahwa aplikasi tersebut bisa digunakan dengan baik dan benar sesuai dengan yang diharapkan. Tahap uji coba pada aplikasi ini dilakukan pada fitur pencarian kata dan tambah kata.

\section{Struktur Navigasi}

Struktur navigasi digunakan untuk membuat alur aplikasi sehingga dapat menganalisis interaksi seluruh obyek pada aplikasi dan interaksi aplikasi dengan pengguna. Aplikasi ini menggunakan struktur navigasi hirarki karena untuk setiap masuk maupun kembali dari halaman satu ke halaman berikutnya hanya dapat dilakukan perpindahan satu tingkat.

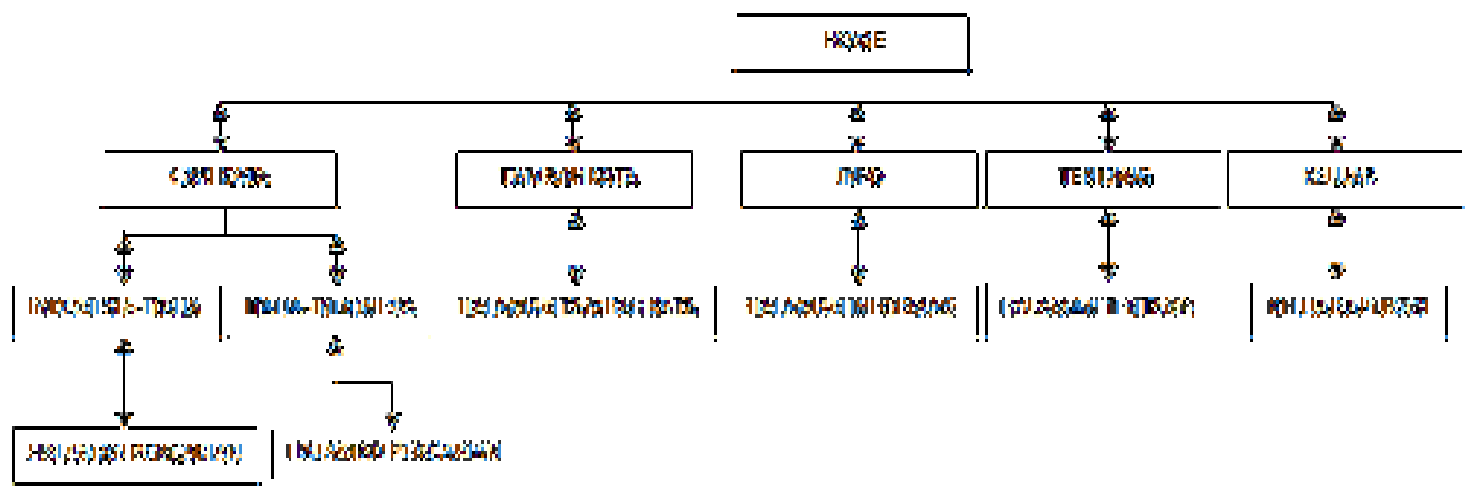

Gambar 3. Struktur Navigasi

Pada halaman awal aplikasi ini terdapat lima pilihan menu yang dapat dipilih, yaitu cari kata, tambah kata, bantuan, tentang, dan keluar. Jika tombol cari kata dipilih maka akan menampilkan pilihan cari kata untuk mencari kata Indonesia-Italia atau Italia-Indonesia. Kedua tombol tersebut akan menampilkan tampilan pencarian kata untuk masing-masing pilihan. Jika user memilih tombol tambah kata maka akan menampilkan halaman penambahan kata untuk melakukan penambahan kata. Jika memilih tombol bantuan maka akan menampilkan tampilan informasi untuk penggunaan aplikasi. Jika tombol tentang dipilih maka keterangan dari aplikasi ini akan ditampilkan. Jika pengguna ingin keluar dari aplikasi maka pengguna memilih tombol keluar.

\section{Rancangan Antar Muka}

Rancangan antar muka adalah rancangan tampilan antar muka. Rancangan antar muka aplikasi mobile kamus bahasa Indonesia - bahasa Italia sebagai berikut:

A. Rancangan Halaman Splash Screen

Halaman awal yang akan ditampilkan pada aplikasi ini adalah halaman splash screen. Halaman ini merupakan sebuah halaman pembuka dari aplikasi untuk menampilkan nama aplikasi. Sehingga ketika aplikasi pertama dijalankan akan tampil satu halaman dalam beberapa detik yang menampilkan latar belakang gambar dan nama aplikasi yaitu Dizionario. 
Dizionario

Gambar 4. Rancangan Tampilan Halaman Splash Screen

B. Rancangan Halaman Menu Utama

Halaman ini menampilkan 5 tombol untuk pilihan menu yang ada pada aplikasi. tombol cari kata untuk pindah ke halaman pencarian kata, tombol tambah kata untuk berpindah ke halaman tambah kata, tombol bantuan untuk pindah ke halaman bantuan, tombol tentang untuk berpindah ke halaman tentang aplikasi, dan tombol keluar untuk keluar dari aplikasi kamus Indonesia-Italia.

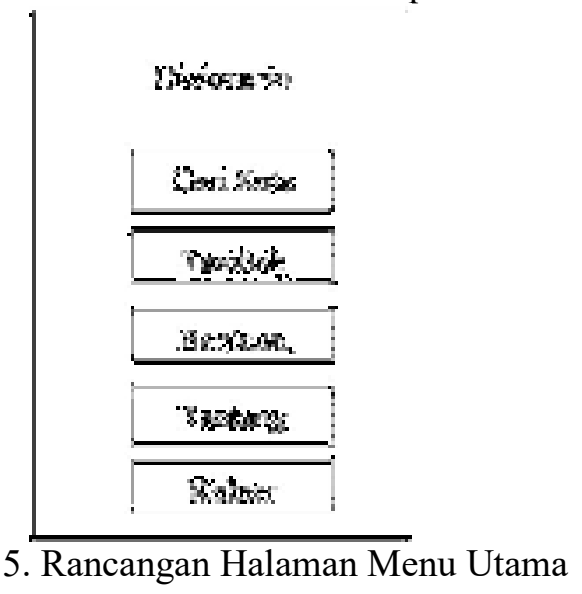

C. Rancangan Halaman Cari Kata Italia

Halaman cari kata Italia akan ditampilkan bila pengguna memilih pilihan menu cari kata pada halaman menu utama kemudian memilih Indonesia-Italia pada menu cari kata. Untuk mencari kata dalam bahasa Italia, masukkan kata dalam bahasa Indonesia. Terdapat input text untuk menuliskan kata bahasa Indonesia dan terdapat text box yang akan menampilkan arti kata dalam bahasa Italia.

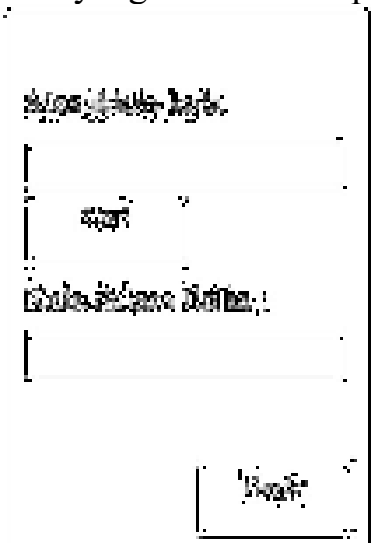

Gambar 6. Rancangan Halaman Cari Kata Italia

D. Rancangan Halaman Cari Kata Indonesia 
Halaman cari kata Indonesia akan ditampilkan bila pengguna memilih pilihan menu cari kata pada halaman menu utama kemudian memilih Italia-Indonesia pada menu cari kata. Untuk mencari kata dalam bahasa Indonesia, masukkan kata dalam bahasa Italia. Terdapat input text untuk menuliskan kata bahasa Italia dan terdapat text box yang akan menampilkan arti kata dalam bahasa Italia.

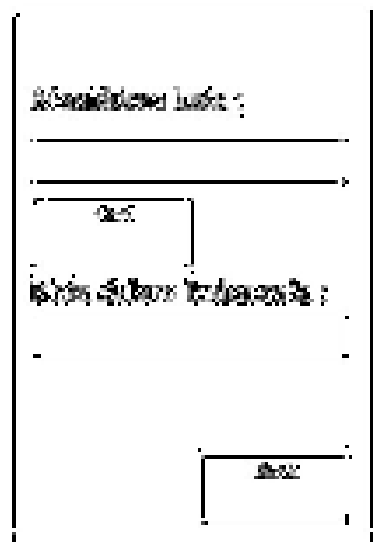

Gambar 7. Rancangan Halaman Cari Kata Indonesia

E. Rancangan Halaman Tambah Kata

Halaman ini akan muncul bila pengguna memilih pilihan menu tambah kata pada menu utama. Halaman ini digunakan untuk menambahkan kata jika kata belum terdapat dalam basisdata aplikasi ini.

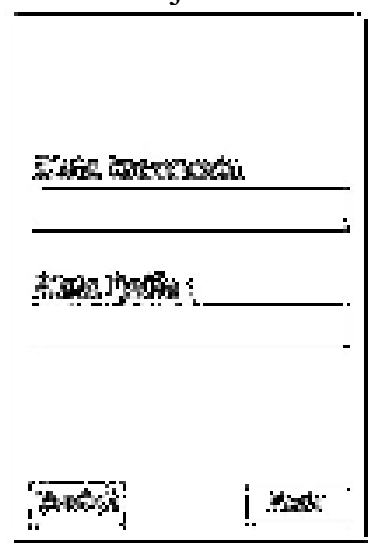

Gambar 8. Rancangan Halaman Tambah Kata

F. Rancangan Halaman Bantuan

Halaman bantuan akan ditampilkan bila pengguna memilih menu bantuan di halaman menu utama. Terdapat informasi dalam bentuk teks yang akan ditampilkan sebagai bantuan bagi pengguna dalam menggunakan aplikasi ini.

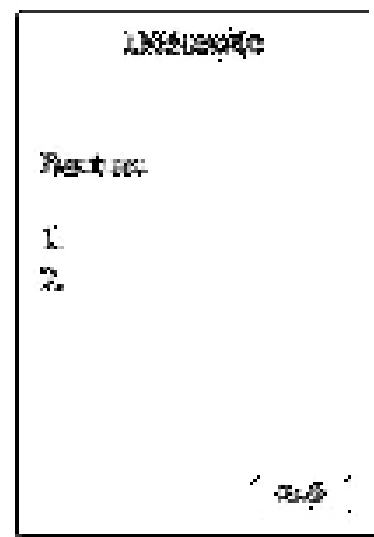

Gambar 9. Rancangan Halaman Bantuan 


\section{Tahapan Pembuatan Aplikasi}

\section{HASIL DAN PEMBAHASAN}

Sesudah tahap perancangan aplikasi diselesaikan maka tahap selanjutnya adalah melakukan proses pembuatan aplikasi yang disesuaikan dengan rancangan alur program dan rancangan tampilan halaman yang telah dibuat. Tahap pembuatan dari aplikasi ini dimulai dengan melakukan pembuatan halaman splash screen, halaman menu utama, halaman cari kata Italia, halaman cari kata Indonesia, halaman tambah kata, halaman bantuan, dan halaman tentang. Gambar-gambar yang digunakan disimpan pada folder drawable yang ada di folder resource (res) dalam bentuk (.png), file tampilan (layout) disimpan pada folder resource (res) dalam bentuk (.xml), dan file program Java disimpan pada folder source (src) dalam bentuk (.java).

\section{Implementasi}

Implementasi adalah tampilan aplikasi yang telah selesai dan dapat digunakan. Implementasi pengguna aplikasi mobile kamus bahasa Indonesia - bahasa Italia sebagai berikut:

\section{A. Halaman Splash Screen}

Pada saat aplikasi ini mulai dijalankan maka akan ditampilkan sebuah halaman splash screen dengan nama aplikasi di bagian tengah halaman sebagai halaman awal dari aplikasi. Halaman ini ditampilkan dalam 5 detik kemudian aplikasi akan menampilkan halaman selanjutnya yaitu halaman menu utama. Gambar 10 menampilkan tampilan halaman splash screen.

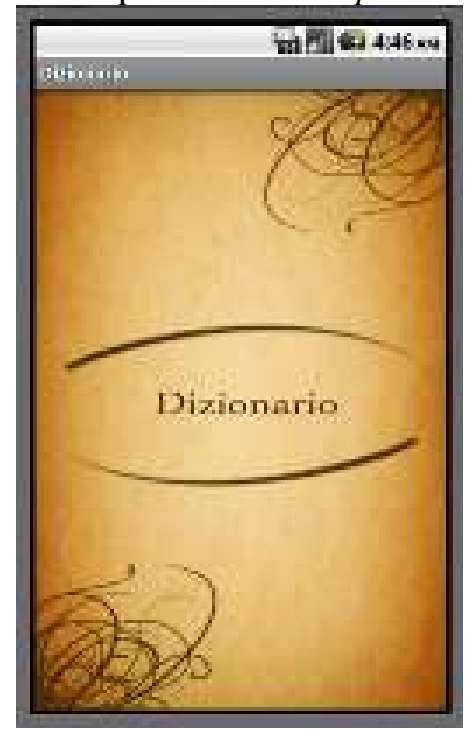

Gambar 10. Halaman Splash Screen

B. Halaman Menu Utama

Pada halaman menu utama terdapat 5 menu yang bisa dipilih oleh pengguna. Tombol cari kata dipilih untuk pindah ke halaman cari kata, tombol tambah kata dipilih untuk pindah ke halaman tambah kata baru, tombol bantuan dipilih untuk pindah ke halaman informasi cara penggunaan aplikasi, tombol tentang dipilih untuk pindah ke halaman informasi mengenai keterangan aplikasi, dan tombol keluar dipilih untuk menghentikan dan keluar dari aplikasi. Gambar 11 menampilkan tampilan halaman menu utama. 


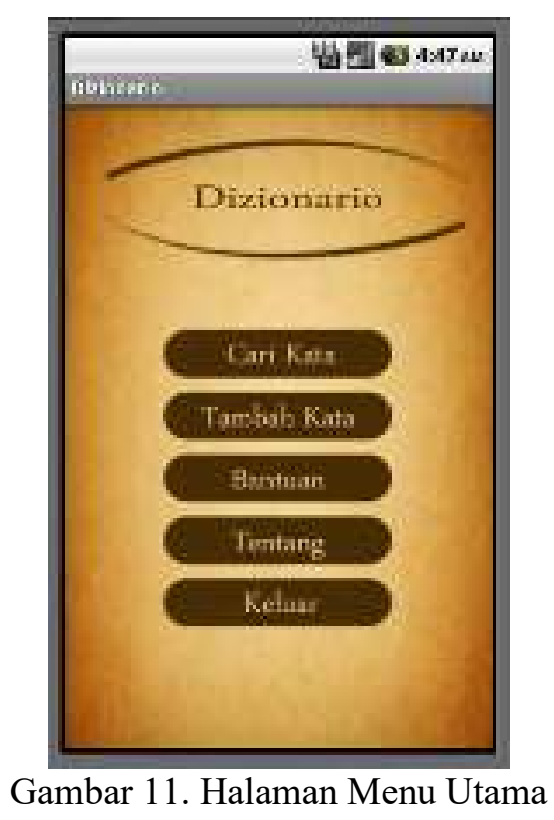

\section{Halaman Cari Kata}

Pengguna dapat mengetik kata pada input text dibagian masukkan kata setelah itu menekan tombol cari kata maka proses pencarian kata akan berjalan. Jika kata yang dicari terdapat dalam basis data aplikasi maka pada textbox terjemahan akan ditampilkan arti dari kata tersebut. Apabila kata yang dicari tidak terdapat dalam basis data aplikasi maka pada pada textbox terjemahan akan ditampilkan tulisan "Kata tidak ditemukan". Gambar 12(a) menampilkan tampilan halaman cari kata Indonesia-Italia dan Gambar 12(b) menampilkan tampilan halaman cari kata Italia-Indonesia.

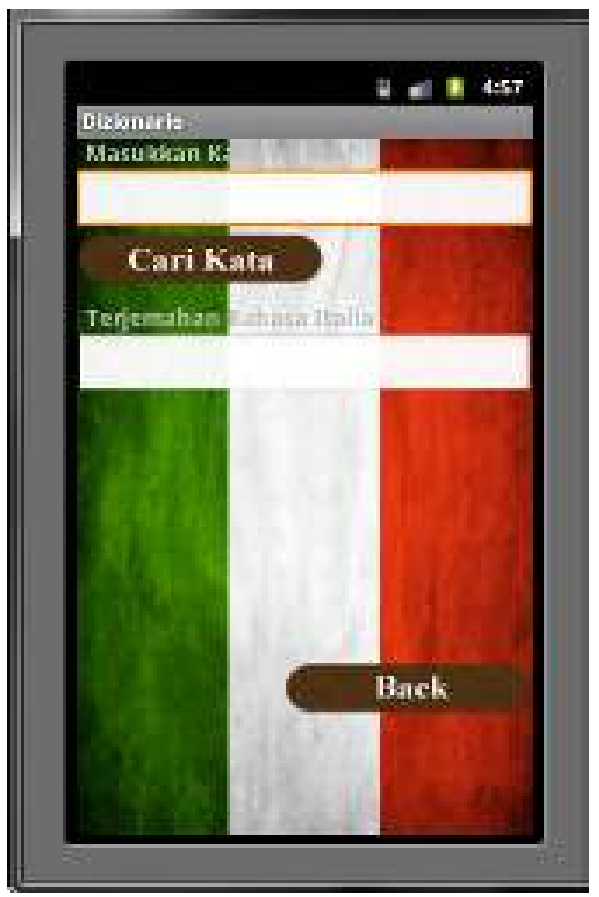

(a) Indonesia-Italia

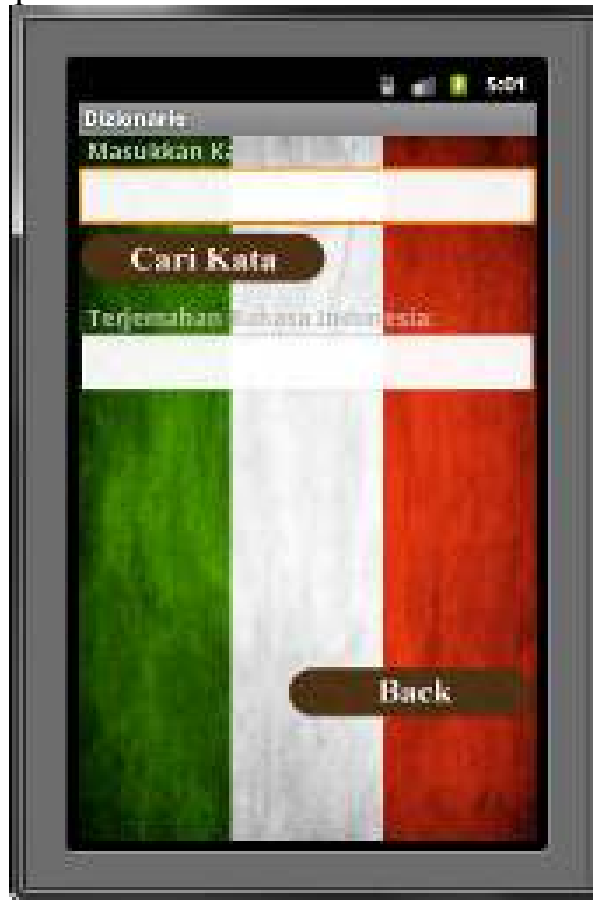

(b) Italia -Indonesia

Gambar 12. Halaman Cari Kata

D. Halaman Tambah Kata

Jika tombol tambah kata di halaman menu utama dipilih oleh pengguna maka halaman tambah kata baru akan ditampilkan. Halaman ini digunakan untuk menambahkan kata baru yg di inginkan oleh pengguna. Gambar 13 menampilkan tampilan halaman tambah kata. 


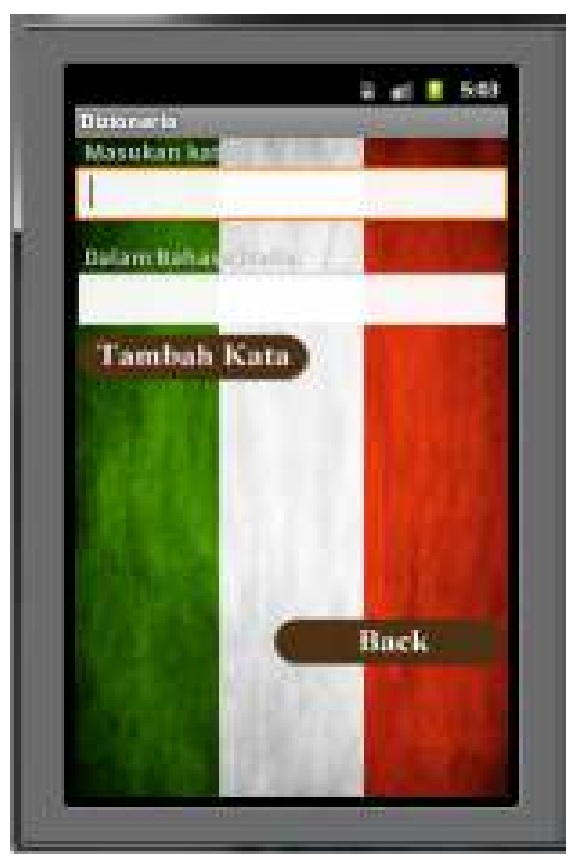

Gambar 13. Halaman Tambah Kata

\section{E. Halaman Bantuan}

Jika tombol bantuan di halaman menu utama dipilih oleh pengguna maka akan ditampilkan halaman informasi cara penggunaan aplikasi. Halaman bantuan memberikan penjelasan mengenai cara penggunaan aplikasi. Gambar 14 menampilkan tampilan halaman bantuan.

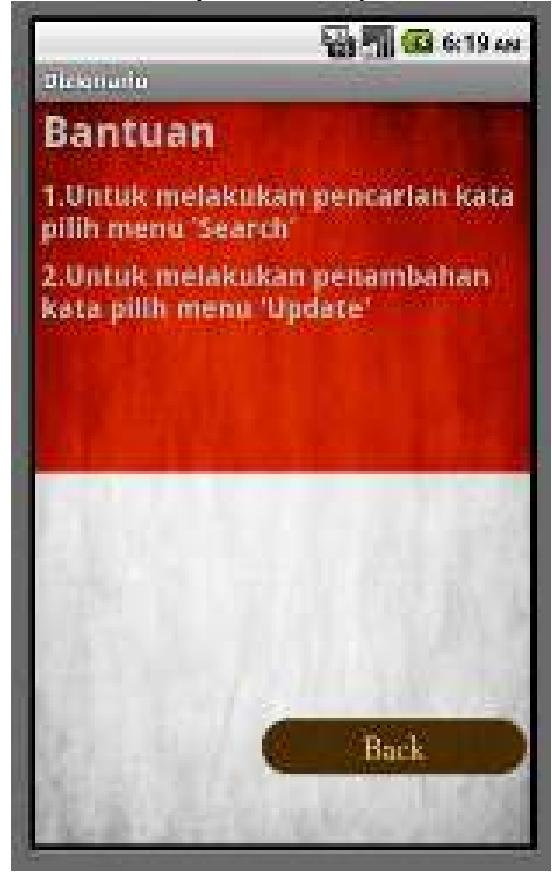

Gambar 14. Halaman Bantuan

\section{Uji Coba Pencarian Kata}

Uji coba pencarian kata dilakukan untuk memastikan bahwa menu pencarian kata pada aplikasi yang sudah dibuat dapat memenuhi harapan dan pengguna bisa menggunakannya dengan baik dan benar. Pencarian kata adalah pencarian arti kata dari Bahasa Indonesia ke Bahasa Italia atau sebaliknya. Pada saat aplikasi dieksekusi, tampilan awal aplikasi yang muncul adalah tampilan Halaman Splash Screen kemudian halaman Menu Utama, seperti yang ditunjukkan pada Gambar 15. (a). Pencarian kata dapat dilakukan oleh pengguna dengan memilih tombol "Cari Kata". Pada layar 
yang tampil (Gambar 15. (b)), pengguna dapat memasukkan kata yang akan dicari pada bagian textbox. Jika pencarian kata yang dilakukan oleh pengguna berhasil, maka layar yang tampil adalah layar yang memuat hasil pencarian (Gambar 15. (c)). Jika kata yang dicari tidak ada, maka akan ditampilkan sebuah pesan pada aplikasi bahwa kata tersebut tidak ada (Gambar 15. (d)).[1]

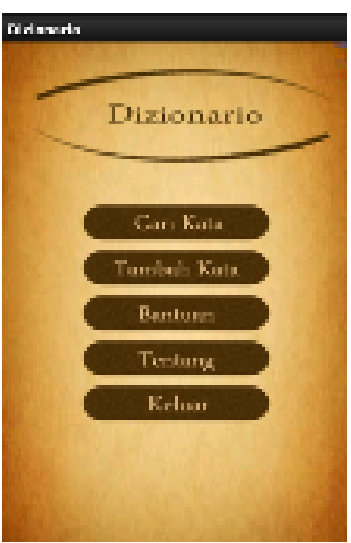

(a)

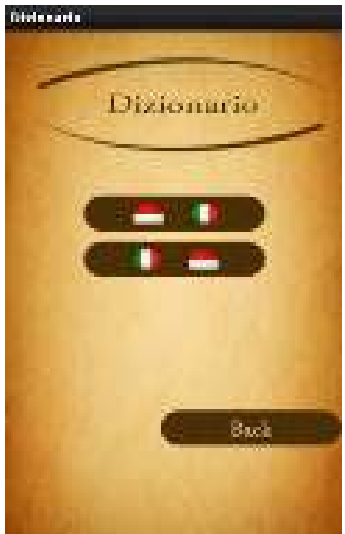

(b)

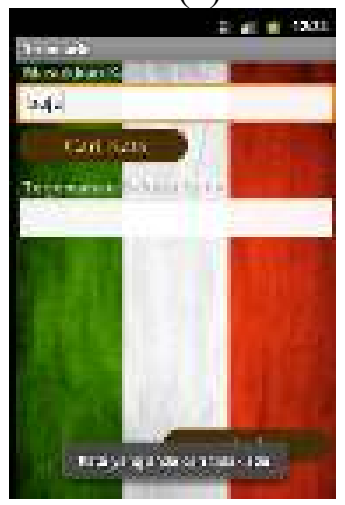

(d)

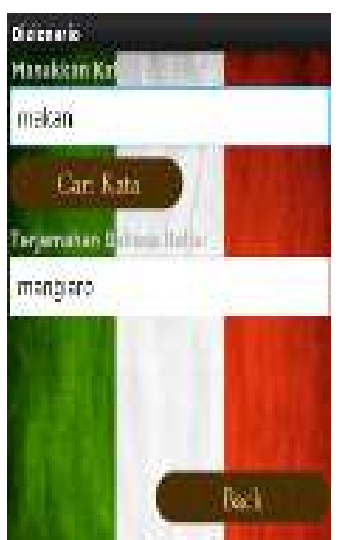

(c)

Gambar 15. Uji Coba Pencarian Kata

\section{Uji Coba Tambah Kata}

Uji coba tambah kata dilakukan untuk memastikan bahwa menu tambah kata pada aplikasi tersebut sudah sesuai dengan harapan dan dapat digunakan dengan baik dan benar. Pencarian Tambah kata adalah penambahan kata baru dalam Bahasa Indonesia dan Bahasa Italia. Pada saat aplikasi mulai dijalankan dan masuk ke halaman menu utama maka akan muncul tampilan seperti pada Gambar 16 (a) kemudian untuk melakukan penambahan kata, pengguna memilih tombol "Tombol Kata". Kemudian akan muncul tampilan seperti pada Gambar 16. (b) jika penambahan kata yang dilakukan telah berhasil.
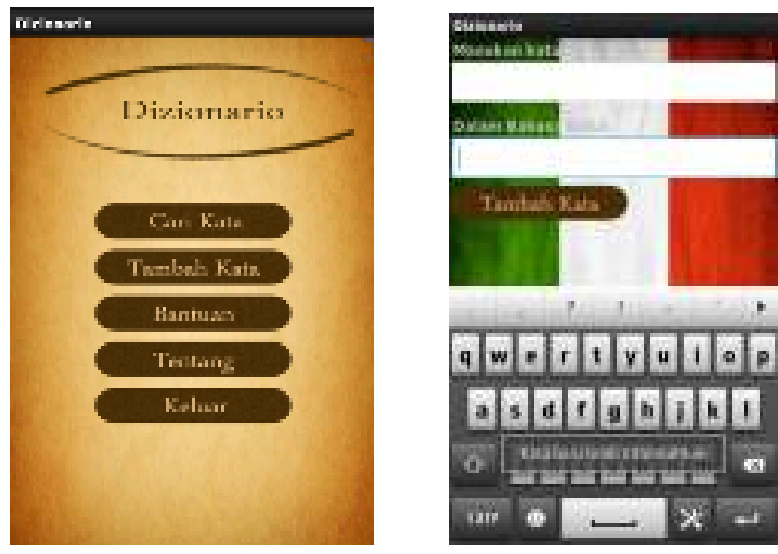
(a)

(b)

Gambar 16. Uji Coba Penambahan Kata

\section{KESIMPULAN}

Setelah dilakukan implementasi dan pengujian terhadap aplikasi kamus bahasa Indonesia bahasa Italia berbasis Android, dapat disimpulkan bahwa aplikasi ini dapat menjadi tambahan referensi dalam pembelajaran bahasa Italia. Aplikasi kamus ini menyediakan dua fitur, yaitu fitur cari kata untuk mencari arti dari Indonesia ke Italia maupun sebaliknya dan fitur tambah kata untuk menambahkan kata baru sesuai keinginan pemakai. Selain itu aplikasi ini juga memberi peringatan jika dalam proses pencarian kata yg dimasukan oleh pengguna tidak ditemukan.

\section{SARAN}

Aplikasi kamus bahasa Indonesia - bahasa Italia ini dapat dikembangkan pada beberapa bagian, seperti melengkapi data yang digunakan supaya informasi yang diberikan oleh aplikasi menjadi lebih menyeluruh dan maksimal. Fitur AutoCompleteTextView jika bisa digunakan pada aplikasi ini untuk membantu pengguna dalam fungsi pencarian kata.

\section{DAFTAR PUSTAKA}

[1] A. Y. F. Pangestu and Rustam, "Aplikasi Kamus Bahasa Jepang Berbasis Mobile Android,” J. Inf. dan Komput., vol. 8, no. 1, pp. 75-80, 2020, doi: 10.35959/jik.v8i1.178.

[2] N. D. Sofya, S. Esabella, and R. -, "Rancang Bangun Aplikasi Kamus Bahasa Sumbawa Berbasis Android," J. Matrik, vol. 17, no. 1, p. 36, 2017, doi: 10.30812/matrik.v17i1.59.

[3] E. Darnila, Safwandi, and N. Fadisar, "Aplikasi Kamus Bahasa Indonesia-Arab Berbasis Android Menggunakan Metode Boyer-Moore,” Techsi, vol. 10, no. 1, pp. 26-38, 2018.

[4] L. O. Kasema, S. R. Sentinuwo, and A. M. Sambul, "Aplikasi Kamus Bahasa Daerah Pasan Berbasis Android," J. Tek. Inform., vol. 13, no. 2, pp. 1-6, 2018, doi:

10.35793/jti.13.2.2018.22489. 